\title{
Economic Culture for Health Educational Managers
}

\author{
Hernandez $\mathrm{FF}^{1 *}$, Gonzalez ES ${ }^{1}$, Perez $\mathrm{BZ}^{2}$ and Lamanier Ramos $\mathrm{JI}^{3}$ \\ ${ }^{1}$ Faculty of Medical Science, University of Medical Science of Havana, Cuba \\ ${ }^{2}$ University of Sciences from the Physical Culture and Sports, Cuba \\ ${ }^{3}$ Faculty of Health Technology, University of Medical Science of Havana, Cuba
}

*Corresponding author: Fe Fernandez Hernández, Faculty of Medical Science "10 de October", at University o Medical Science of Havana, Cuba, Email: fefh@infomed.sld.cu

\section{Research Article \\ Volume 4 Issue 5}

Received Date: August 25, 2021

Published Date: September 06, 2021

DOI: $10.23880 /$ jqhe-16000238

\section{Abstract}

Introduction: The present Public Health development shows the necessity to add economic subjects to the teaching-learning process because of the close relation between economic and health variables. The economic culture may provide the necessaries tools for rational decision taking. These reasons show that the economic culture upping from the health educational managers must be understood as a main subject for the managing process.

Objective: To describe the importance from the economic culture for the health educational managers.

Materials and methods: Was made a descriptive research about the importance from the economic culture upping for the health educational managers. As teoric methods were used the analysis and synthesis, the comparative and the inductivedeductive. As empiric method was used the bibliographic research.

Results: The economic upping from the health educational managers focuses the attention from the health universities because of the impact from the health educational behavior over the health educational process. Health universities are management institutions where the role of decisions taking is decisive. That's why is important each time more a better forming in economic culture to provide a better patient satisfaction across the optimization from the limited economic resources.

Conclusion: The postgraduate education must support an effective economic culture upping for health educational managers. By this way the health educational process may supply solutions to upping needs from these managers. In this way, the economic culture offers useful tools to health educational managers for a better managing behavior.

Keywords: Economic Culture; Health Education Manager; Health University

\section{Introduction}

The constant changes at present age, the globalization, the fast technological development, the aging and the present health context determine transformations in the policy, the economy and the society too. At same time, these transformations means new challenges for the Public Health as sector responsibilities with the people health and the human develop [1]. Universities are conditioned by these processes too. Because of that in raising way had wined relevancy the mutual cooperation between universities and others institutions [2]. Postgraduate education for the Public Health plays a decisive role in the formation and development from the health human resources since health concepts. These are remaking constantly the health professionals role front of problems agree to the principles of the university education. That's why the academy must be serving to developing sectors from production and services and extending the university field out from the university campus.

Postgraduate education is at present the highest educational form from the superior education responsibilities with the real supply of processes for the professional upping. 
It is formed by two main subjects: the professional upping and the academic formation. The first must cover the upping activities. These must be close related to productivity raising, the efficiency and the labor quality. Te second must manager the higher forming processes as PhD and MD too [3].

The present Public Health development shows the necessity to add economic subjects to the teaching - learning process because of the close relation between economic and health variables such as the costs from the health-illness process and the morbidity, mortality and life quality. That's why the educational health manager must analyze the social context since an economic perspective, identify the main relations between health and economy and manage agree to these relations [4]. Present tendencies from the process of the economic culture upping from the health educational managers are focused on main needs from health universities. In much case this is because many health educational managers hadn't a sufficient formation in economic subjects $[5,6]$.

The professional upping in economic culture must be a complement forming subject for the health educational managers. Economy don't offer solution to all and each question from the health educational managing process. However, much from the health educational managing contexts are close related to economic subjects [7]. The insufficiency from the economic resources carries to take decisions moreover than the health and the education in pure context. In these cases the economic culture may provide the necessaries tools for rational decision taking. These reasons show that the economic culture upping from the health educational managers must be understood as a main subject for the managing process [8].

\section{Objective}

To describe the importance from the economic culture for the health educational managers.

\section{Materials and Methods}

Was made a descriptive research about the importance from the economic culture upping for the health educational managers. As teoric methods were used the analysis and synthesis, the comparative and the inductive-deductive. As empiric method was used the bibliographic research.

\section{Results}

The optimization use from the available economic resources carried to use economic tools in the context of the social relations. Thus was possible a better adaptation adding these economic tools to the common living [9]. Then, the economic culture plays a main role for the human society because includes the whole economic cultural elements assumed by previous generations [10]. Economic culture provides a reference context controlling social relations. This culture form was perfected agreed to problems solution from the social relations. Thus the economic culture establishes a teoric-practice context for the socioeconomic human behavior [11].

At international context the economic culture development had been very heterogeneous agree to the own develop from the society researched [12]. In that way the including of economic knowledge to the educational process pointed an inflexion point in the dynamic from the social learning for the socioeconomic development. Thus the professional upping in economic culture became in a real need from the higher education processes and the health education isn't excluded [13]. The educational institutionalization emphasized much more the main role from the educational process for the develop of the economic culture. Particularly the higher education headed it development in all social contexts resulting higher social development across the economic culture development too [14].

Agree to the social develop, the economic subjects inclusion to the educational process continue being a growing need for all sciences. Each time more are needed professionals capacity with effective tools for a better professional behavior agree to the particular needs from the society. Thus these knowledge's contribute perfecting the professional behavior from the health educational managers $[15,16]$. The economic culture plays a main role for the value formation for health educational managers. Agree to these managers upping and awaring the relevancy from the work, the save and the efficiency, would be possible a better answer to several problems from the production and services too $[17,18]$.

Professional upping in economic culture for the health educational managers: a present need from the management develop the economic upping from the health educational managers focus the attention from the health universities because of the impact from the health educational behavior over the health educational process [19]. The Public Health universities are management institutions where the role of decisions taking is decisive. That's why is important each time more a better forming in economic culture to provide a better patient satisfaction across the optimization from the limited economic resources [20]. Health educational mangers must assume several roles in the assistant, the researching, the educational and the administration context at same time. That's why they need a sufficient academic formation to provide a whole answer to all and each question 
in the health educational management process $[21,22]$.

Economic sciences and Health sciences aren't divorced. Since an economic point of view the health may be considered than especial economic good. By other side the economy is a social determining from the health which extension depends from the own particularities from the researched society. However, the economic culture from the health educational manager must provide a more extensive understanding moreover these main trues [23]. The professional upping in economic culture from the health educational manager don't becomes it in an economist. However, this economic culture may provide useful tools for a better understanding of the social context related to the manager and administration from the health educational process $[24,25]$.

Health universities as academic and researching institutions related to the technical and social develop, must research the better experiences and provide professional upping programs agree to the particular and new needing from the health educational managers. Then, economic culture upping from the health educational managers must be a structural subject from the general upping from these managers [26].

The postgraduate education in the national health system has as main objective the continue upping from all health educational professionals. This continues upping must create new opportunities for alternative ways researching solutions to several current problems without solution out the alternatives from the economic culture. Thus the professors group from the health university will be more capacity to manager the teaching - learning process too [27]. It isn't necessary wait until last time to introduce the economic culture in the formation of health educational managers. Neither is good may it as single decision. The organization from the educational process agree to the economic culture formation must may a better beginning at job market for the health educational manager as main person with high capability to inside in the economy and the society too [28].

Thus the economic culture is a main part from a more complex process to obtain a whole culture for significant transformation needed in the society where the health educational manager acts. That's why the economic culture upping for health educational managers must be understood as a singular need for them and the society too and this particular culture form must characterize the health educational manager behavior in manager activities $[29,30]$. Life is considered holy because of the limited life time. Then, the life and the life time must be considered as especial economic goods where the health educational managers must play a significant role compromised with the individual and social welfare. This expected behavior must be supported by a rational decision taking based on a strong economic culture [31].

In this sense the health educational role is determinant because of the direct influence in the formation of the health human resources. Then, the formation of health human resources with high capability to take retional decision based and supported by a sufficient economic culture provides important elements to make better the usual relation between the patient and the health professional agree to the particular characteristic from the health social system. Thus, the economic culture upping for the health educational managers offer a practice and Metrologic guide to optimize the use of the limited economic resources available in the health system [32]. The health human capital will be revaluated each time more with inclusion of health economy subjects in their formation [33,34]. Public Health must be agree to the human develop tendency and then the economic culture upping from the health educational manages is a present social and political need [35].

Efficiency from the economic culture upping for the health sector must be evidenced by discriminant between all needs agree to the priority ranking. Each health worker must understand the real need from the personal upping in economic subjects and health institutions must provide the material conditions for that particular upping. This argument shows the responsibility from the health educational institutions respect to the health human capital upping. These institutions must be compromised with the professional develop from their workers and identify the particular and specific postgraduate upping needs and provide possible spaces for that professional growing including in economic culture for the health educational managers agree to institutional strategies [36]. The economic culture upping for health educational managers must be agreed to the own characteristic from the health educational institution. Also, this upping form must be selective agree to the identified need from institutions and managers at same time [37].

\section{Economic Culture and Public Health}

The economic problems in an extended way are showed in each social sector where the health education isn't excluded. The health educational services need important economic resources to cover it. Then, the economic culture define a rational life style agree to the main principles defined socially and particularly by the health education [38].

The human develop is determined by the real economic resources available and any social sector has limited disponibility of those resources. Then, the higher develop rate is conditioned to the optimization use from the 
economic resources, showing the protagonist role from the economic culture in the administration processes [39]. Much economic terms are often utilized by common people much time in empirical way without understand the relevancy from the economic culture in that vocabulary and behavior. This fact make emphasis in the main role form the economic culture for the society and shows the real need to manager appropriately the economic culture using process [40].

The health education isn't excluded from this reality. Health educational manager must play an appropriate role supported on economic rationality moreover of common sense, supported in a strong economic culture. This culture type must be a teoric - practice reference for the health educational manager for the best labor behavior. As consequence, the economic culture must be incorporate to the common thinking from each health educational manager. The best example of the mutual relation between Economic Sciences and Health Sciences is the Health Economy. This is a young science but is present in the health services administration, illness cost research and health financial administration for example [41].

The mutual relation between Economy and Health is close determined by social determining. By one side the Economy main objective is close related to mutual relationship between people. By other side, the Public Health is focused on living and life quality. Both sciences have social subjects in common and these subjects must be assumed to stronger formation of health educational managers. To obtain that objective the health educational manager needs an intensive upping in economic subjects agree to the economic culture needed for it management process [43].

\section{The Professional Upping from the Health Educational Managers and Their Importance for the Permanent Formation}

The forming process from the health educational managers must be a priories subject from the health education system. At present, challenges from health universities carry to a new educational process supported in principles of Excellency and quality too. One of the more significant challenges at present is the quantity and quality of health professional forming at health universities. This process is close related to politic, social and economic changes applied in the practice in mutual relation with society demands $[44,45]$.

The consolidations of the educational model from the new health university it developing in a social and historic context determined by new conditions. As consequence it is necessary to remake the teoric bases assumed until present for a better adaptability from health universities and provide them the possibility of better uncertain future management [46]. Changes because of Health University develop carry to a growing dynamic with more demanding context around the formation of health professors and health educational managers. This condition shows the raising demand of health professionals with sufficient academic preparation to provide effective solutions to present challenges supported in economic subjects.

\section{Conclusion}

The postgraduate education must support an effective economic culture upping for health educational managers. By this way the health educational process may supply solutions to upping needs from these managers. In this way, the economic culture offers useful tools to health educational managers for a better managing behavior.

\section{References}

1. Mérida Mingarro AR, Sánchez Paz N (2019) Methodology for The Analysis Of Hospital And Economic Efficiency In Health Institutions. Caribbean Journal of Social Sciences.

2. Zambrana JV, Cabrera Elejalde OR, Paula Acosta CA(2017) Theoretical-methodological conception of the process of formation of the economic culture of educational cadres. University and Society 9(2): 275-282.

3. Ruiz RB, Izquierdo NV, Roger Reyes MA (2020) From continuing medical education to continuing professional development based on competencies. Higher Medical Education 34(2).

4. González Reyes LL, Pino MM (2017) Quality cost management in the Holguín Drugstore. Holguín Medical Scientific Mail 21(4): 955-968.

5. Rodríguez RG (2018) Pedagogical improvement needs in managers of the Comprehensive General Medicine specialty. INFODIR 27: 64-70.

6. González ES, Hernández FF (2020) Diploma course: "Health Economy tools for taking decisions", a useful tool for health managers. Clinical Reviews and Clinical Trials $2(2)$.

7. Ricardo Herrera L, Velázquez Zaldívar R, Torralbas Blázquez AL (2018) Improvement of human capital management in economic areas of universities. Industrial Engineering 39(3): 237-249.

8. Hernández FF, González SE (2020) Health Economic Evaluations for the Health Education Management. International Journal of Education Advancement pp: 100002. 
9. Kuchkarova NM, Atadjanova BT (2020) Development of the economic culture of future primary school teachers based on an integrated approach. Journal of Critical Reviews 7(6): 1134-1137.

10. Serrano Mantilla HB, Serrano Mantilla GL, Gaibor Vera FM (2017) Challenges of strategic planning in health institutions. Cuban Journal of Biomedical Research: 36(3).

11. Bustamante Alfonso LM (2017) The improvement in the health sector from the theory of advanced education. Cuba. 2012-2014. Panorama Cuba and Health 12(1): 5255.

12. Díaz RH, Alfonso JP (2016) Economic culture as a component of comprehensive general culture in the training of Pedagogical Sciences students. Amauta Magazine 15(29): 143-157.

13. Mamanazarov A (2019) Pedagogical bases of formation of economic culture. Scientific periodical of the Polish Academy of Sciences 32(1): 60-67.

14. González LL, García del Sol JA, González OC (2017) The economic culture a current look. University and Society 10(1): 360-364.

15. Pol Miró AE (2019) Concepto de Education and its Relationship with Economic Growth in the EU-28. Business Dimension: 17(4).

16. Concepción OG, Sánchez AG, Gómez IA (2018) Management to strengthen the preparation and improvement of municipal cadres and reserves. Management challenges 12(1): 38-62.

17. Rodríguez HM, Vázquez DP, Oliva BF (2018) Overcoming strategy to improve the work of management of the heads of the teaching department of the Faculty of Medical Sciences "General Calixto García". Higher Medical Education 32(1): 141-154.

18. Jacas IS (2017) Strategic planning in the Cuban Health System. MEDISAN 21(5): 635-641.

19. Polier MO, González HS, Ordoñez Hernández JD (2019) Training of managers and reserves: a necessity for Higher Medical Education institutions. Rev Panorama. Cuba and Health 14(1): 100-102.

20. Quintana Galende ML, Nayra Victoria NI, Medrano TR (2020) Diploma in Public Health Education as a contribution to health training. Cuban Journal Higher Medical Education, 34(1).

21. Gómez YA, Borges Oquendo LC, Añorga Morales JA
(2018) The medical specialties and the human behavior of their coordinators from the perspective of Advanced Education. Panorama. Cuba and Health 13(2): 95-104.

22. Herrera LJ, Gálvez González AM (2019) Economic components of the Costa Rican context that are related to Universal Health. INFODIR 29: 123-137.

23. Cruz JS, Legrá LC, Mustelier Ramos LC (2018) Need for cost studies at the Guantanamo University of Medical Sciences. Scientific Information Magazine 97(1): 76-85.

24. García González MC, León Ramentol CC, Labarcena BR (2016) Strategy for the professional improvement of the health technologist in clinical laboratory. Medical Humanities 16(2): 336-359.

25. Mestre Fernández EB, Lazo Díaz LM, Delgado YB (2017) The training of university teachers for the treatment of health education. Pedagogy and Society 20(48): 163183.

26. Molerio Rosa LC, Sánchez Orbea GN, Urías Arboláez GC (2017) Pertinence of determining the needs for teacher improvement to apply the institutional educational project. EDUMECENTRO 9(1): 1-14.

27. Pineda NT (2018) The formation and qualification of the civil servants and directors of the Public Administration. Public Administration Dossier: 159-174.

28. Bayanova AR, Vodenko KV, Sizova ZM (2019) A philosophical view of organizational culture policy in contemporary universities. European Journal of Science and Theology 15(3): 121-131.

29. Jorna Calixto AR, Véliz Martínez PL (2020) Research on quality in completion works of the Health Organization and Administration Specialty. Higher Medical Education 34(2): 1954.

30. Hernández RR, Martín García MS, Ugarte JI (2017) The Predetermined cost based on hospital care protocols as a tool for management control. COFIN 1: 1-12.

31. Legrá Álvarez RC, García AF, Herrera MC (2018) Activity based costing for management decisions in health. INFODIR 28: 109-119.

32. Iglesias AG, Alarcón MM, Acosta YR (2019) Economic culture and training of human resources for development in the Cuban university. COODES 7(1): 42-53.

33. Escalante LA, Hernández LR, Aldana SP (2018) Professional improvement in a Cuban Medical University/Professional Improvement in a Cuban Medical University. Edu Méd Super 32(4): 38-46. 
34. Fernández Canals RE, Carbonell Pérez JE (2017) The education-economy relationship. A look from the sciences of education. VARONA 64: 1-13.

35. Santana MA (2018) Economic activity in the network of institutions of the Ministry of Higher Education, in support of the work of Cuban higher education. Cuban Journal of Higher Education 1: 94-107.

36. Hernández González BL, González VG, Domínguez KR, Pumar GML, Esperance Céspedes TA, et al. (2018) Professional development in the National Institute of Workers' Health of Cuba, 2013-2017. Cuban Journal of Health and Work 19(3): 51-57.

37. González CE, Herrera IP, Pupo Ávila NL (2021) The academic profession in health: education or training?. Higher Medical Education 35(1): 2130.

38. Quintero CM, Delgado HC, Soler Porro AB (2021) Strategic planning in health institutions. Infodir 34: 990.

39. Olonilua D, Marrero Araújo MC, Crespo LH (2019) Health from the perspective of the allocation of budgetary resources and health outcomes for Cuba and countries of America. 2005-2015. INFODIR 28: 80-97.

40. Reyes RM, Gil EG, Reyes MV (2018) Training in Economics in the Municipality of San Nicolás, Mayabeque Province,
Cuba. Scientific Journal Hallazgos 21 3(2): 144-153.

41. Vélez Mendoza PP, Espinosa Martínez EG (2018) Financial and budgeting planning in higher education institutions in Ecuador. Havana coffin 12(2): 280-294.

42. Díaz AA (2017) Cost-benefit as a decision tool in investment in scientific activities. Havana coffin 12(2): 322-343.

43. Fernández MD (2017) Assessment Of The Impact Of The Exceeding Of The Terms Of Public And Business Administration In Cuba. Cuban Journal of Public and Business Administration 1(1): 3-18.

44. Hernández FF, González ES (2020) A postgraduate course for the decision taking in the Public Health context. Journal of Medical Care Research and Review 3(08): 413-416.

45. Concepción OG, Sánchez AG, Gómez IA (2018) Management to strengthen the preparation and improvement of municipal cadres and reserves. Management challenges 12(1): 38-62.

46. Alonso Betancourt LA, Hechavarría IR, Pérez EP (2021) The pedagogical professional training of the tutor of middle technicians in public health entities. Medical Scientific Mail 25(3). 